\title{
MENDORONG PEMBENTUKAN PERATURAN DAERAH TENTANG BANTUAN HUKUM DI PROVINSI SUMATERA UTARA
}

(Encourage of Establishing Regional Regulation Concerning Legal Aid at Province of North Sumatera)

\author{
Eka N.A.M. Sihombing \\ Kantor Wilayah Kementerian Hukum dan HAM Provinsi Sumatera Utara \\ Jl. Putri Hijau No.4, Medan, Sumatera Utara 20112 \\ Email: ekahombing@gmail.com
}

Naskah diterima: 15 April 2013; revisi: 17 April 2013; disetujui: 20 April 2013

\begin{abstract}
Abstrak
Undang-Undang (UU) Bantuan Hukum memberi ruang bagi daerah untuk mengalokasikan dana penyelenggaraan bantuan hukum dalam APBD. Apabila daerah berkehendak mengalokasikan dana bantuan hukum dalam APBD, maka pemerintah daerah dan DPRD harus mengaturnya dalam Peraturan Daerah (perda). Sampai saat ini, di Provinsi Sumatera Utara belum memiliki Peraturan Daerah yang secara khusus menjamin terlaksananya hak konstitusional warga negara tersebut, khususnya bagi orang atau kelompok orang miskin. Metode penelitian yang digunakan pada penulisan ini menggunakan metode penelitian hukum normatif, dengan pendekatan yuridis normatif (legal research). Sifat penelitian ini adalah deskripsi analitis yaitu suatu penelitian yang bertujuan untuk mendeskripsikan (menggambarkan) tentang fakta dan kondisi atau gejala yang menjadi objek penelitian, setelah itu dilakukan telaah secara kritis. Hasil Penelitian menunjukkan bahwa sampai saat tulisan ini dibuat, ranperda tentang bantuan hukum belum dilakukan penyusunan, masih sekedar dicantumkan dalam Prolegda 2013. Mengingat pentingnya perda tentang bantuan hukum sebagai landasan hukum bagi daerah untuk memenuhi hak-hak masyarakat miskin dalam mengakses keadilan dan perlakuan yang sama di hadapan hukum, dibutuhkan komitmen kuat dari DPRD maupun Pemerintah Daerah Provinsi Sumatera Utara beserta stakeholder untuk segera mengimplementasikan pembentukan perda Bantuan hukum serta mengalokasikan dana bantuan hukum dalam APBD sebagaimana amanat pasal 19 UU Bantuan Hukum.
\end{abstract}

Kata kunci: Pembentukan, Perda, Bantuan Hukum

\section{Abstract}

The law on legal aid gave space for the region to allocate costs of legal aid in the APBD. When the region has an intention to allocate funds in the $A P B D$, local government and the parliaments should be arrange it in regional regulation (Perda). Until now, the province of North Sumatra has not been having regional regulation which specifically guarantees implementation of constitutional rights citizens, especially for people or poor society. Research method used on this paper is normative legal research with normative juridical approach. The nature of research is analytical descriptive that aims to describe about facts and condition or indication which became the object of research, after was done critical studies. The result of research shows that up to the time of writing, Ranperda on legal aid has not been drafting, just simply listed in Prolegda 2013. considering the importance of Perda on legal aid as a legal foundation for the region to fulfill the rights poor society in accessing justice and equal treatment before the law, it takes high commitment from the council and local government of the Province of North Sumatra and its stakeholders to implementing immediately the formation of Perda on legal aid and allocated in the budget as mandated by article 19 the law on legal aid.

Keywords: establishment, regional regulation, legal aid 


\section{A. Pendahuluan}

Dalam rangka menjamin hak konstitusional bagi setiap warga negara yang mencakup perlindungan hukum, kepastian hukum, persamaan di depan hukum, dan perlindungan hak asasi manusia, Pada tanggal 04 Oktober 2011 Pemerintah dan DPR telah menyetujui bersama undang-undang yang mengatur bantuan hukum (Undang-Undang Nomor 16 Tahun 2011 tentang Bantuan Hukum, selanjutnya disebut UU Bantuan Hukum). Kehadiran UU Bantuan Hukum ini paling tidak menjawab ekspektasi yang tinggi dari masyarakat akan penyelesaian persoalan bantuan hukum di Indonesia, dimana sampai saat ini masih banyak rakyat Indonesia yang tak mendapatkan akses terhadap bantuan hukum.

Penyelenggaraan pemberian bantuan hukum kepada masyarakat merupakan upaya pemerintah untuk memenuhi dan sekaligus sebagai implementasi negara hukum yang mengakui dan melindungi serta menjamin hak asasi warga negara akan kebutuhan akses terhadap keadilan (access to justice) dan kesamaan di hadapan hukum (equality before the law). Undang-Undang Bantuan Hukum menjadi dasar bagi negara untuk menjamin warga negara khususnya bagi orang atau kelompok orang miskin untuk mendapatkan akses keadilan dan kesamaan di hadapan hukum. UU Bantuan Hukum membebankan kewajiban kepada Pemerintah untuk mengalokasikan dana penyelenggaraan bantuan hukum dalam APBN. Pendanaan penyelenggaraan Bantuan Hukum dialokasikan pada anggaran kementerian yang menyelenggarakan urusan pemerintahan di bidang hukum dan hak asasi manusia, dalam hal ini Kementerian Hukum dan HAM RI. Secara eksplisit disebutkan bahwa penyelenggara bantuan hukum adalah Pemerintah melalui Kemenkumham RI yang dilaksanakan oleh Lembaga Bantuan Hukum (LBH) maupun Organisasi Kemasyarakatan (Ormas). Namun Pembentuk UU bantuan hukum menyadari bahwa dana yang dialokasikan dalam APBN tidak akan mampu untuk memenuhi semua permohonan bantuan hukum yang ada di seluruh daerah. Untuk itu UU bantuan hukum mendelegasikan kepada Pemerintah Daerah untuk mengalokasikan dana penyelenggaraan bantuan hukum dalam APBD sebagaimana dimaksud dalam Pasal 19 Undang-Undang Bantuan Hukum. Sampai saat ini, di Provinsi Sumatera Utara belum memiliki Peraturan Daerah yang secara khusus menjamin terlaksananya hak konstitusional warga negara tersebut, khususnya bagi orang atau kelompok orang miskin. Padahal menurut data BPS 2012 Provinsi Sumatera Utara termasuk salah satu Provinsi yang penduduk miskinnya berjumlah diatas 1 juta. ${ }^{1}$

Selama ini, pemberian Bantuan Hukum yang dilakukan belum banyak menyentuh orang atau kelompok orang miskin, sehingga mereka kesulitan untuk mengakses keadilan karena terhambat oleh ketidakmampuan mereka untuk mewujudkan hak-hak konstitusional mereka. Pengaturan mengenai pemberian Bantuan Hukum Untuk Masyarakat Miskin dalam Peraturan Daerah merupakan jaminan terhadap hak-hak konstitusional orang atau kelompok orang miskin di Sumatera Utara. 


\section{B. Permasalahan}

Berdasarkan hal tersebut diatas untuk mencari jawaban atas permasalahan tersebut perlu dilakukan penelitian hukum yang khusus ditekankan pada permasalahan mengapa diperlukan Peraturan Dareah Tentang Bantuan Hukum di Provinsi Sumatera Utara?

\section{Metode Penelitian}

Penelitian yang dilakukan adalah penelitian hukum normatif, yakni penelitian yang dilakukan dengan menganalisis permasalahan dengan menggunakan azas-azas hukum dan prinsip-prinsip hukum. Peneliti ingin melihat sejauh mana ketentuan-ketentuan hukum yang menjadi dasar dan landasan bagi permasalahan yang sedang dibahas dengan menggunakan metode penelitian Studi Kepustakaan (Library Research).

Sifat penelitian ini adalah deksriftif analitis yaitu suatu penelitian yang bertujuan untuk mendeskripsikan (menggambarkan) tentang fakta dan kondisi atau gejala yang menjadi objek penelitian, setelah itu dilakukan telaah secara kritis, dalam arti memberikan penjelasanpenjelasan atas fakta atau gejala tersebut, baik dalam kerangka sistematisasi atau sinkrosnisasi, dengan berdasarkan pada aspek yuridis dengan demikian akan menjawab permasalahan yang menjadi objek penelitian.

Didalam penelitian ini digunakan beberapa pendekatan, dengan pendekatan tersebut peneliti akan mendapatkan informasi dari berbagai aspek mengenai permasalahan yang sedang dicari jawabannya. Penelitian ini sendiri akan menggunakan metode pendekatan normatif atau pendekatan peraturan (statute approach). Pendekatan ini dilakukan dengan menelaah semua peraturan perundangundangan dan regulasi yang berkaitan dengan permasalahan yang menjadi objek penelitian ini. Pendekatan normatif dimaksudkan untuk memecahkan permasalahan yang merupakan objek permasalahan dalam penelitian yaitu untuk meninjau dasar dan prinsip hukum mengenai pembentukan Peraturan Daerah tentang Bantuan Hukum. Pengumpulan data ditempuh dengan melakukan studi dokumen dan sebagai data pendukung dilakukan dialog dengan pihak yang terkait, dalam hal ini peneliti melakukan dialog dengan Staf Ahli Badan Legislasi DPRD Provinsi Sumatera Utara.

\section{Pembahasan}

\section{Teori Keadilan dan Persamaan di depan hukum}

Keadilan adalah hak dasar manusia yang yang patut dihormati dan dijamin pemenuhannya. Akses terhadap keadilan pada intinya berfokus pada dua tujuan dasar dari keberadaan suatu sistem hukum, yaitu sistem hukum seharusnya dapat diakses oleh semua orang dari berbagai kalangan dan seharusnya dapat menghasilkan ketentuan maupun keputusan yang adil bagi semua kalangan, baik secara individual maupun kelompok. ${ }^{2}$ Gagasan dasar yang hendak diutamakan dalam konsep ini adalah untuk mencapai keadilan sosial (social justice) bagi seluruh warga negara.

Keadilan sosial sendiri didefinisikan sebagai "Distribusiyang adilatas kesehatan, perumahan,

Kementerian Negara Perencanaan Pembangunan Nasional/Badan Perencanaan Pembangunan Nasional, Pokja Akses terhadap Keadilan Kementerian Negara Perencanaan Pembangunan Nasional/ Badan Perencanaan Pembangunan Nasional (BAPPENAS), Strategi Nasional dan Akses terhadap Keadilan, (Jakarta: BAPPENAS, 2009), hlm. ix. 
kesejahteraan, pendidikan dan sumber daya hukum di masyarakat, termasuk jika perlu adanya tindakan afirmasi untuk distribusi sumber daya hukum tersebut terhadap disadvantages groups". ${ }^{3}$ Dalam definisi ini, secara langsung dikatakan bahwa akses terhadap keadilan mengandung tujuan untuk mendistribusikan sumberdaya hukum kepada kelompok yang secara ekonomi kekurangan. Pemenuhan hak atas bantuan hukum mempunyai arti negara harus menggunakan seluruh sumberdayanya termasuk di dalam bidang eksekutif, legislatif dan administratif untuk mewujudkan hak atas bantuan hukum secara progresif.

Salah satu ciri pada suatu negara hukum yang demokratis adalah adanya pengakuan dan jaminan terhadap Persamaan dihadapan hukum (Equality Before The Law). Equality before the law berasal dari pengakuan terhadap individual freedom bertalian dengan hal tersebut Thomas Jefferson menyatakan bahwa "that all men are created equal" terutama dalam kaitannya dengan hak-hak dasar manusia. Pasal 27 ayat (1) UUD 1945 menyatakan bahwa segala warga negara bersamaan kedudukannya di dalam hukum dan pemerintahan dan wajib menjunjung hukum dan pemerintahan itu dengan tidak ada kecualinya, artinya, semua orang diperlakukan sama di depan hukum. Dengan demikian konsep Equality before the Law telah diintodusir dalam konstitusi, suatu pengakuan tertinggi dalam sistem peraturan perundang-undangan di tanah air. $^{4}$
Persamaan dihadapan hukum itu sendiri juga merupakan salah satu hak asasi manusia yang dilindungi oleh konstitusi. Oleh karena itu, setiap warga negara selalu mendapat tempat yang sama dihadapan hukum, artinya, siapapun warga negara yang tinggal dalam suatu negara diperlakukan sama satu sama lain baik dalam memperoleh hak sebagai warga negara maupun diperlakukan dihadapan hukum. Secara teoritis, persamaan merupakan prinsip atau asas yang melekat pada hakikat manusia sebagai ciptaan Tuhan Yang Maha Kuasa. ${ }^{5}$ Istilah persamaan dalam Bahasa Inggris disebut "Equality". Menurut International Encyclopedia of The Social Sciences sebagaimana dikutip Ramly Hutabarat ${ }^{6}$, apabila dikatakan manusia adalah sama namun dalam kenyataannya terdapat ketidaksamaannya karena karakteristik manusia yang memiliki perbedaan. Karakteristik itu didasarkan pada perbedaan seks, warna, karakter watak dan sebagainya juga didasarkan pada berbagai institusi manusia yang berbeda seperti perbedaan kewarganegaraan agama, tingkat sosial dan sebagainya. David L. Sill yang mengeditEncyclopedia tersebutmengemukakan antara lain: ${ }^{7}$

That men are equal means thet men share some qualities: this must be specified men are evidently unequal in many characteristics. There are natural differences. (Sex, colour, character traits, natural endowment, etc). Other properties are common amounts (age, strength, intelligence, power, etc)

3 Muhammad Zaidun, dkk, Mengajarkan Hukum Yang Berkeadilan; Cetak Biru Pembaharuan Pendidikan Hukum Berbasis Keadilan Sosial (Jakarta: ILRC, 2009).

4 Rusma Dwiyana, Equality Before The Law VS Impunity: Suatu Dilema, (Makalah tanpa tahun), hlm. 2-3.

5 Ramly Hutabarat, Persamaan di Hadapan Hukum sebagai Antithese terhadap Diskriminasi Hukum, (Makalah disampaikan dalam Seminar Sehari yang diadakan oleh staf ahli Kementerian Hukum dan HAM RI pada tanggal 1 Desember 2011 di Aula Pengayoman Kantor Wilayah Kementerian Hukum dan HAM Sumatera Utara), hlm. 3. Ibid.

Ibid. 
Substansi yang mengemuka dalam International Encyclopedia of the Social Science ini bahwa manusia itu adalah sama, hanya berdasarkan karakteristiknya manusia memiliki perbedaan. ${ }^{8}$ Teori Equality, jika dibedah, paling tidak dapat dibagi dalam empat bagian, yaitu: ${ }^{9}$

\section{Natural Equality (Persamaan Alamiah)}

Natural Equality adalah persamaan yang dibawa dari lahir yang dimiliki oleh manusia. Manusia adalah sama karena semua manusia sebagai ciptaan Tuhan sama-sama memiliki rasio yang membedakannya dari binatang.

2. Civil Equality (Persamaan Hak Sipil)

Civil Equality adalah hak sipil yang sama bagi setiap warga negara. Umpamanya setiap orang memiliki hak yang sama dihadapan hukum tanpa diskriminasi.

3. Political Equality (Persamaan Politik)

Political Equality adalah hak yang sama dalam politik. Artinya setiap orang memiliki kesempatan yang sama dalam memberikan suara dalam pemilihan umum, memiliki hak yang sama memasuki partai politik dan sebagainya.

4. Economic Equality (Persamaan Ekonomi)

Economic Equality adalah persamaan kesempatan dalam meningkatkan taraf ekonomi. Hak-hak ekonomi warga negara adalah sama dan dilindungi oleh konstitusi yang berlaku.

Teori "Equality Before The Law" berdasarkan empat klasifikasi itu dimasukkan ke dalam Teori Civil Equality yaitu hak-hak sipil. Hak seperti ini dijamin dan dilindungi oleh konstitusi sehingga dihadapan hukum semua orang wajib diperlakukan sama. Tidak dikenal adanya tebang pilih atau berat sebelah atau menempatkan orang-orang tertentu sebagai warga negara kelas satu. Inilah yang disebut oleh David L. Sill sebagai "impartially" artinya tidak berat sebelah. Itulah sebabnya Teori Equality Before The Law merupakan antitesis terhadap diskriminasi hukum. ${ }^{10}$

Dari pengertian mengenai persamaan dihadapan hukum yang disampaikan oleh beberapa ahli secara substansi terdapat persamaan unsur-unsur yang terdapat didalamnya, yaitu bahwa persamaan dihadapan hukum pada prinsipnya merupakan hak setiap orang diperlakukan sama oleh hukum, sekalipun mereka berasal dari status sosial yang berbeda.

\section{Hak Atas Bantuan Hukum}

Hak atas bantuan hukum telah diterima secara universal. Hak bantuan hukum dijamin dalam International Covenant on Civil dan Political Rights (ICCPR), UN Standard Minimum Rules for the Administration of Juvenile Justice, dan UN Declaration on the Rights of Disabled Persons. Hak ini dikategorikan sebagai non-derogable rights, hak yang tak dapat dikurangi dan tak dapat ditangguhkan dalam kondisi apapun. Hak ini merupakan bagian dari keadilan prosedural, sama dengan hak-hak yang berkaitan dengan independensi peradilan dan imparsialitas hakim. Pemenuhan keadilan prosedural ini tidak dapat dilepaskan dari keadilan substantif, yaitu hak-hak yang dijamin dalam berbagai konvensi internasional.

Di Indonesia, meskipun Bantuan Hukum tidak secara tegas dinyatakan sebagai tanggung jawab negara namun ketentuan Pasal 1 ayat (3) Undang-Undang Dasar Negara Republik Indonesia Tahun 1945 menegaskan bahwa 
"Negara Indonesia adalah negara hukum". Dalam negara hukum, negara mengakui dan melindungi hak asasi manusia bagi setiap individu termasuk hak atas Bantuan Hukum. Penyelenggaraan pemberian Bantuan Hukum kepada warga negara merupakan upaya untuk memenuhi dan sekaligus sebagai implementasi negara hukum yang mengakui dan melindungi serta menjamin hak asasi warga negara akan kebutuhan akses terhadap keadilan (access to justice) dan kesamaan di hadapan hukum (equality before the law). Hal ini terdapat dalam Pasal 1 ayat (3) Perubahan Ketiga Undang-Undang (UUD) 1945, Pasal 27 UUD 1945 dan Putusan Mahkamah Konstitusi No. 006/PUU-II/2004. Dalam negara hukum (rechtstaat) negara mengakui dan melindungi hak asasi manusia setiap individu, sehingga semua orang memiliki hak untuk diperlakukan sama di hadapan hukum (equality before the law). Persamaaan di hadapan hukum harus diartikan secara dinamis dan tidak statis. Persamaan di hadapan hukum harus diimbangi oleh persamaan perlakuan (equal treatment). Hal ini didasarkan pula pada Pasal 34 ayat (1) UUD 1945 yang menyatakan bahwa "Fakir miskin dan anak-anak yang terlantar dipelihara oleh negara". Dalam hal ini negara mengakui hak ekonomi, sosial, budaya, sipil dan politik dari fakir miskin. Maka atas dasar pertimbangan tersebut, tahanan yang masuk dalam kategori fakir miskin/tidak mampu memiliki hak untuk diwakili dan dibela oleh advokat/pembela umum baik di dalam maupun di luar pengadilan (legal aid) sama seperti orang mampu yang mendapatkan jasa hukum dari advokat (legal service). Penegasan ini memberikan implikasi bahwa bantuan hukum bagi fakir miskin atau yang tidak mampu merupakan tugas dan tanggung jawab negara dalam pemenuhannya.
Hak untuk mendapatkan peradilan yang adil, adalah hak bagi setiap tersangka sebagai warga negara. Untuk dapat menuju terwujudnya suatu peradilan yang adil, maka kepada Tersangka/ Terdakwa berhak untuk mendapatkan Bantuan Hukum, yang bertujuan untuk melindungi tersangka dari tindakan kesewenang-wenangan yang dilakukan oleh penegak hukum dalam proses hukum, berupa pelanggaran hak-hak tersangka, pemaksaan, dan kesewenangwenangan. Bantuan Hukum merupakan suatu kewajiban yang wajib diberikan kepada setiap warga khususnya tersangka dalam perkara pidana pada setiap proses pemeriksaan, yang bertujuan untuk mewujudkan adanya suatu sistem peradilan pidana yang dijalankan dengan menghormati hak-hak konstitusional dan asasi setiap warga negara dengan menjunjung tinggi asas praduga tak bersalah. Dengan adanya pemberian Bantuan Hukum yang dilakukan oleh Penasihat Hukum/ Advokat, maka suatu proses persidangan akan berjalan dengan seimbang (audi et alteram partem), oleh karena para pihak dapat memberikan pendapatnya secara bebas dan proporsional, sehingga suatu peradilan yang adil dapat terwujud.

Hak untuk memperoleh keadilan (access to justice) merupakan hak asasi yang dimiliki setiap warga negara. Negara sebagai pelindung dan pemerintah, wajib untuk memberikan perlindungan dan pembelaan kepada setiap warga negara atas adanya perlakuan yang tidak adil yang dialami warga negara. Bahwa berdasarkan amanah dalam UUD 1945, setiap warga memiliki persamaan kedudukan di dalam hukum, dan berhak atas perlindungan hukum yang adil, serta persamaan perlakuan hukum, sehingga hak-hak warga negara berdasarkan konstitusi wajib dijamin dan dilindungi oleh negara dalam suatu peraturan perundang- 
undangan. Dalam Amandemen kedua UUD 1945 di dalam Pasal 28 I ayat (4) menyatakan bahwa: Perlindungan, Pemajuan, Penegakan, dan Pemenuhan Hak Asasi Manusia adalah tanggung jawab Negara, terutama Pemerintah. Hal ini semakin jelas, bahwa Negara berperan dan bertanggung jawab dalam pemenuhan hak konstitusional dan pemenuhan hak asasi warga negaranya secara penuh.

Setiap warga negara berhak untuk mendapatkan hak-haknya dalam suatu proses peradilan, yang bertujuan untuk melindungi individu warga negara atas adanya kesewenangwenangan dan perampasan hak-hak dasar manusia. Untuk terciptanya suatu tujuan tersebut, maka adanya suatu pengaturan yang konkret mengenai pemberian Bantuan Hukum merupakan suatu hal yang tidak dapat ditawar lagi, aturan tersebut dapat dijadikan satu bab khusus secara lengkap dalam KUHAP. Bantuan Hukum yang konkret bukanlah Bantuan Hukum yang sifatnya limitatif atau terbatas, namun merupakan suatu bantuan hukum yang tanpa batas dan secara lengkap (ad infinitum), yang dapat diakses dan diberikan kepada setiap warga negara khususnya masyarakat miskin yang sedang menjalankan proses pemeriksaan dalam suatu perkara pidana maupun perdata.

Black's Law Dictionary mendefinisikan bahwa bantuan hukum adalah "Country wide systemadministered locally by legal services is rendered to those in financial need and who can not afford private counsel." Menurut The International Legal Aid, bantuan hukum didefinisikan sebagai "The legal aid work is an accepted plan under which the services of the legal profession are made available to ensure that no one is deprived of the right to receive legal advice or, where necessary legal representation before the courts or tribunals, especially by reason of his or her lack of financial resources". ${ }^{11}$

Selain itu, menurut Adnan Buyung Nasution, bantuan hukum adalah sebuah program yang tidak hanya merupakan aksi kultural akan tetapi juga aksi struktural yang diarahkan pada perubahan tatanan masyarakat yang tidak adil menuju tatanan masyarakat yang lebih mampu memberikan nafas yang nyaman bagi golongan mayoritas. ${ }^{12}$ Oleh karenanya bantuan hukum bukanlah masalah sederhana, melainkan sebuah rangkaian tindakan guna pembebasan masyarakat dari belenggu struktur politik, ekonomi, dan sosial yang sarat dengan penindasan.

Lebih lanjut Frans Hendra Winarta menyimpulkan bahwa bantuan hukum merupakan jasa hukum yang khusus diberikan kepada fakir miskin yang memerlukan pembelaan secara cuma-cuma, baik di luar maupun di dalam pengadilan, secara pidana, perdata, dan tata usaha negara, dari seseorang yang mengerti seluk beluk pembelaan hukum, asas-asas dan kaidah hukum, serta hak asasi manusia. ${ }^{13}$

Menurut pendapat Mauro Cappelletti, bantuan hukum bagi si miskin umumnya diartikan sebagai pemberian jasa-jasa hukum, kepada orang-orang yang tak mampu untuk menggunakanjasa-jasaadvokatatauprofessional lawyers. Meskipun motivasi ataupun alasan dari pada pemberian bantuan hukum kepada si miskin ini berbeda-beda dari jaman ke jaman,

\footnotetext{
11 Frans H. Winarta, Bantuan Hukum di Indonesia, (Jakarta: Elex Media, 2009), hlm. 21.

12 Frans Hendra Winarta, Pro Bono Publico: Hak Konstitusional Fakir Miskin Untuk Memperoleh Bantuan Hukum, (Jakarta: Gramedia Pustaka Utama, 2009), hlm. 22.

13 Ibid., hlm. 23.
} 
namun ada satu hal yang kiranya tidak berubah, sehingga merupakan satu benang merah, yaitu dasar kemanusiaan. ${ }^{14}$

Menurut pendapat Barry Metzger, bahwa program bantuan hukum di negara-negara berkembang, pada umumnya mengambil arti dan tujuan yang sama seperti di barat, yang pada dasarnya terdiri dari dua bagian yaitu, pertama, bahwa bantuan hukum yang efektif adalah merupakan syarat yang esensial untuk berjalannya fungsi maupun integritas peradilan dengan baik; dan kedua, bahwa bantuan hukum merupakan tuntutan dari rasa kemanusiaan. ${ }^{15}$

Dalam Peraturan Pemerintah Republik Indonesia Nomor 83 Tahun 2008 tentang Persyaratan dan Tata Cara Pemberian Bantuan Hukum Secara Cuma-Cuma, bantuan hukum secara cuma-cuma adalah jasa hukum yang diberikan advokat tanpa menerima pembayaran honorarium meliputi pemberian konsultasi hukum, menjalankan kuasa, mewakili, mendampingi, membela, dan melakukan tindakan hukum lain untuk kepentingan pencari keadilan yang tidak mampu.

Berdasarkan uraian tersebut di atas, dapat diketahui bahwa dalam bantuan hukum terdapat beberapa unsur, yaitu:

a. penerima bantuan hukum adalah fakir miskin atau orang yang tidak mampu secara ekonomi;

b. bantuan hukum diberikan baik di dalam maupun di luar proses peradilan;

c. bantuan hukum diberikan baik dalam lingkup peradilan pidana, perdata maupun tata usaha negara; d. bantuan hukum diberikan secara cumacuma.

\section{Pengaturan Bantuan Hukum di Indonesia}

Pengaturan mengenai bantuan hukum di Indonesia pada dasarnya tersebar dalam berbagai peraturan perundang-undangan. Peraturan perundang-undangan yang secara khusus mengatur mengenai Bantuan Hukum adalah Undang-Undang Bantuan Hukum, sementara ketentuan mengenai bantuan hukum terdapat pula dalam pasal 22 ayat (1) Undang-Undang Nomor 18 Tahun 2003 tentang Advokat, yang menyebutkan bahwa Advokat wajib memberikan bantuan hukum secara cuma-cuma kepada pencari keadilan yang tidak mampu. Secara lebih spesifik aturan ini termuat juga dalam Kode Etik Perhimpunan Advokat Indonesia (PERADI) pasal 7 point (h) bahwa Advokat mempunyai kewajiban untuk memberikan bantuan hukum secara cuma-cuma (pro deo) bagi orang yang tidak mampu.

Selain itu Pemerintah juga telah mengeluarkan Peraturan Pemerintah Nomor 83 tahun 2008 tentang Persyaratan dan tata Cara Pemberian Bantuan Hukum secara cuma-cuma. Pasal 1 mendefinisikan bantuan hukum cumacuma adalah jasa hukum yang diberikan advokad tanpa menerima pembayaran honorarium meliputi pemberian konsultasi hukum, menjalankan kuasa, mewakili, mendampingi, membela, dan melakukan tindakan hukum lain untuk kepentingan pencari keadilan yang tidak mampu. Definisi pencari keadilan yang tidak mampu adalah orang perseorangan

Mauro Cappelletti, Toward Equal justice : A Comparative Study of Legal Aid in Modern Societies, (New York: Dobbs Ferry, 1975 ), hlm. 25.

15 Barry Metzger, Legal Services to the Poor and National Development Objectives, dalam buku Legal Aid and World Poverty, (Preger Publishers, 1974), hlm. 5. 
atau sekelompok orang yang secara ekonomis tidak mampu yang memerlukan jasa hukum untuk menangani dan menyelesaikan masalah hukumnya.

Peraturan perundang-undangan yang mengamanatkan untuk pemberian bantuan hukum kepada para pencari keadilan yang tidak mampu yang lain dapat dilihat juga dalam Undang-Undang Nomor 48 Tahun 2009 Tentang Kekuasaan Kehakiman, serta pada UndangUndang Nomor 49 Tahun 2009 Tentang Peradilan Umum yang dibahas di Pasal 68B dan Pasal 68C, yang isinya adalah setiap orang yang berperkara mendapatkan bantuan hukum, Negara yang menanggung biaya perkara tersebut, pihak yang tidak mampu harus melampirkan surat keterangan tidak mampu harus melampirkan surat keterangan tidak mampu dari kelurahan tempat domisili yang bersangkutan, serta setiap Pengadilan Negeri agar dibentuk Pos Bantuan Hukum kepada para pencari keadilan yang tidak mampu dalam memperoleh bantuan hukum secara cuma-cuma kepada semua tingkat peradilan sampai putusan terhadap perkara tersebut memperoleh kekuatan hukum tetap.

Hak atas bantuan hukum adalah bagian dari proses peradilan yang adil dan inherent di dalam prinsip negara hukum dan merupakan salah satu prinsip HAM yang telah diterima secara universal. Hal ini dinyatakan dalam Pasal 7 Deklarasi Umum Hak Asasi Manusia (DUHAM), yang menjamin persamaan kedudukan di muka hukum dan dijabarkan dalam International Covenant on Civil dan Political Rights (ICCPR) atau Konvensi Hak Sipil dan Politik.

Pasal 16 dan Pasal 26 ICCPR menjamin bahwa semua orang berhak untuk perlindungan dari hukum serta harus dihindarkan adanya diskriminasi berdasarkan apapun termasuk status kekayaan. Sedangkan Pasal 14 ayat
(3) menjamin hak atas bantuan hukum dan memerintahkan negara untuk menyediakan Advokat/Pemberi Bantuan Hukum (PBH) yang memberikan bantuan hukum secara efektif untuk masyarakat miskin dan ketika kepentingan keadilan mensyarakatkannya.

Selain DUHAM dan ICCPR, hak atas bantuan hukum terdapat dalam UN Standard Minimum Rules for the Administration of Juvenile Justice, terkait pentingnya hak atas bantuan hukum bagi anak yang berkonflik dengan hukum, UN Declaration on the Rights of Disabled Persons terkait pentingnya bantuan hokum yang berkualitas pada orang-orang difable (different ability). Hak Bantuan hukum dikategorikan sebagai non-derogable rights (tak dapat dikurangi),

Secara khusus hak bantuan hukum dijamin dalam Pasal 17, 18, 19 dan 34 Undang-Undang Nomor 39 Tahun 1999 tentang HAM, UndangUndang Nomor 14 Tahun 1970 tentang Ketentuan Pokok Kekuasaan Kehakiman, dengan perubahannya dalam Undang-Undang Nomor 35 Tahun 1999, khususnya Pasal 35 yang menyatakan setiap orang yang tersangkut perkara berhak memperoleh bantuan hukum. Hak inipun melekat pada perumusan hak tersangka/terdakwa, saksi dan korban dalam berbagai peraturan perundang-undangan yang bersifat sektoral, seperti dalam UndangUndang Nomor 8 Tahun 1981 tentang Kitab Undang-Undang Hukum Acara Pidana (KUHAP), Undang-Undang Nomor 12 Tahun 2005 tentang Konvensi Hak Sipil dan Politik, Undang-Undang Nomor 7 Tahun 1984 tentang Ratifikasi CEDAW, Undang-Undang Nomor 23 Tahun 2002 tentang Perlindungan Anak, Undang-Undang Nomor 13 Tahun 2006 tentang LPSK dan UU tentang Perdagangan Orang. 
Dalam Ketentuan Peralihan UU Bantuan Hukum ditegaskan bahwa pada Tahun 2013 Kementerian Hukum dan Hak Asasi Manusia Republik Indonesia akan secara penuh melaksanakan tugas dan fungsi sekaligus penganggarannya pada tahun 2013. Lebih lanjut Dalam ketentuan Pasal 24 UU Bantuan Hukum disebutkan bahwa:

\begin{abstract}
"pada saat undang-undang ini mulai berlaku, semua peraturan perundang-undangan yang mengatur mengenai bantuan hukum dinyatakan masih tetap berlaku sepanjang tidak bertentangan dengan ketentuan dalam undang-undang ini."
\end{abstract}

Dengan demikian segala peraturan perundang-undangan yang mengatur bantuan hukum sebagaimana telah diuraikan diatas, masih tetap berlaku sepanjang tidak bertentangan dengan Undang-Undang Bantuan Hukum.

\section{Pembentukan Perda Tentang Bantuan Hukum di Provinsi Sumatera Utara}

Kehadiran Undang-Undang Bantuan Hukum menimbulkan konsekuensi pembebanan kewajiban kepada Pemerintah untuk mengalokasikan dana penyelenggaraan bantuan hukum dalam APBN. Pendanaan penyelenggaraan Bantuan Hukum dialokasikan pada anggaran kementerian yang menyelenggarakan urusan pemerintahan dibidang hukum dan hak asasi manusia dalam hal ini Kementerian Hukum dan HAM RI. Namun Pembentuk UndangUndang Bantuan Hukum menyadari bahwa dana yang dialokasikan dalam APBN tidak akan mampu untuk memenuhi semua permohonan bantuan hukum yang ada di seluruh daerah. Untuk itu Undang-Undang Bantuan Hukum melalui ketentuan Pasal 19 memberi ruang bagi daerah untuk mengalokasikan dana penyelenggaraan bantuan hukum dalam APBD. Undang-Undang Bantuan Hukum memang tidak membebankan kewajiban bagi daerah untuk mengalokasikan dana penyelenggaraan bantuan hukum, karena dalam ketentuan Pasal 19 ayat (1) menggunakan frasa 'dapat', sehingga tersedia pilihan bagi daerah apakah akan mengaturnya atau tidak. Akan tetapi apabila daerah berkehendak mengalokasikan dana bantuan hukum dalam APBD, maka pemerintah daerah dan DPRD harus mengaturnya dalam Peraturan Daerah (Perda). Sampai saat ini, di Provinsi Sumatera Utara belum memiliki Peraturan Daerah yang secara khusus menjamin terlaksananya hak konstitusional warga negara tersebut, padahal menurut data yang dilansir Badan Pusat Statistik pada akhir Tahun 2012 ada 6 provinsi di Indonesia yang memiliki jumlah penduduk miskin di atas 1 juta jiwa, yaitu Jawa Tengah dengan penduduk miskin sebanyak 4,9 juta, Jawa Barat dengan penduduk miskin sebanyak 4,5 juta, kemudian Sumatera Utara dengan penduduk miskin 1,4 juta. Lampung dengan penduduk miskin sebanyak 1,25 juta, Sumatera Selatan mempunyai penduduk miskin 1,06 juta, Nusa Tenggara Timur sebanyak 1,01 juta, dan DKI Jakarta mencapai 363,2 ribu. ${ }^{16}$ Sebaran penduduk miskin di Sumatera Utara terbilang cukup merata antara pedesaan dan perkotaan. Tercatat dari sekira 1.378.400 penduduk miskin yang ada, sekira 669.300 orang berada di perkotaan. Namun data jumlah penduduk miskin ini masih akan sangat bias jika dibandingkan dengan tingkat Kebutuhan Hidup

16 Jawa Timur Terbanyak Dihuni Penduduk Miskin, http://www.rmol.co/news.php?id=90145 (diakses tanggal 22 April 2012). 
Layak (KHL) di Sumatera Utara yang diperkirakan mencapai Rp1,5 juta. ${ }^{17}$ Penduduk miskin yakni penduduk yang memiliki rata-rata pengeluaran per kapita per bulan di bawah garis kemiskinan. Sementara untuk September 2012, garis kemiskinan dari 1,378 juta jiwa tersebut berkisar Rp271.738 per kapita per bulan, naik 3,68 persen jika dibandingkan Maret 2012 yang hanya dari Rp262.102 per kapita per bulan. ${ }^{18}$ Berdasarkan pengamatan peneliti, ${ }^{19}$ Pemberian Bantuan Hukum yang dilakukan selama ini di Provinsi Sumatera Utara belum banyak menyentuh orang atau kelompok orang miskin, sehingga mereka kesulitan untuk mengakses keadilan karena terhambat oleh ketidakmampuan mereka untuk mewujudkan hak-hak konstitusional mereka. Padahal pengaturan mengenai pemberian Bantuan Hukum Untuk Masyarakat Miskin dalam Peraturan Daerah merupakan jaminan terhadap hak-hak konstitusional orang atau kelompok orang miskin di Sumatera Utara.

Beberapa daerah yang ada di Indonesia telah merespons ketentuan Pasal 19 UU Bantuan Hukum dengan menerbitkan Perda tentang Bantuan Hukum diantaranya Provinsi Jawa Timur, dan beberapa daerah kabupaten/ kota. Bahkan Provinsi Sumatera Selatan yang notabene penduduk miskinnya menurut data BPS lebih sedikit dibandingkan dengan Provinsi Sumatera Utara telah mengundangkan Perda tentang Bantuan Hukum bagi Masyarakat miskin, walaupun daerah yang telah menerbitkan perda bantuan hukum jumlahnya masih belum signifikan dibandingkan dengan yang belum menerbitkan Perda Bantuan Hukum.

Provinsi Sumatera Utara sendiri pada tanggal 14 Desember 2012 DPRD telah menetapkan Program Legislasi Daerah Tahun 2013 melalui Keputusan Nomor 16/K/2012, dalam keputusan tersebut DPRD menetapkan 37 (tiga puluh tujuh) usulan Rancangan Peraturan Daeraha (ranperda) dalam Prolegda, dengan rincian 15 (lima belas) ranperda usul inisiatif DPRD Provinsi Sumatera dan 22 (dua puluh dua) ranperda usul prakarsa Pemerintan Provinsi Sumatera Utara.

Salah satu ranperda usul inisiatif DPRD Provinsi Sumatera Utara adalah Ranperda Tentang Bantuan Hukum. Sampai tulisan ini dibuat, proses pembentukan perda bantuan hukum masih belum dilakukan penyusunan, masih sekedar dicantumkan dalam Prolegda 2013. Bahkan Naskah Akademik, Penjelasan dan/ atau keterangan belum tersusun. Padahal, ketika Ranperda telah dicantumkan dalam Prolegda, seharusnya Naskah Akademik, Penjelasan dan/ atau keterangan telah tersusun pula. Belum tersentuhnya penyusunan ranperda tentang Bantuan Hukum disebabkan DPRD Sumatera Utara maupun Pemerintah Provinsi Sumatera Utara masih memiliki beban ranperda Luncuran

17 Jumlah Penduduk Miskin Sumut Diklaim Tinggal 10\%, http://economy.okezone.com/ $\mathrm{read} / 2013 / 01 / 03 / 20 / 740611 / j u m l a h-p e n d u d u k-m i s k i n-s u m u t-d i k l a i m-t i n g g a l-10$ (diakses pada tanggal 22 April 2013).

18 Ibid.

19 Pada awal Januari sampai dengan akhir Oktober 2010 peneliti pernah menjabat sebagai Kepala Sub Seksi Bantuan Hukum dan Penyuluhan pada Rumah Tahanan Negara Klas I Medan, dalam kurun waktu tersebut peneliti sering melakukan dialog kepada tahanan maupun narapidana yang termasuk dalam kategori miskin, dan sebagian besar dari mereka tidak mendapatkan hak atas bantuan hukum. Selain itu, pada Tahun 2011, Peneliti juga merupakan salah satu anggota Tim Penelitian Hukum Kanwil kementerian Hukum dan HAM Sumatera Utara dengan judul: "Pemenuhan Hak Atas Bantuan Hukum Bagi Tahanan di Lembaga Pemasyarakatan, Rumah Tahanan Negara dan Cabang Rumah Tahanan Negara di Provinsi Sumatera Utara". Dari hasil penelitian juga menunjukkan bahwa masih banyak tahanan (dalam kategori miskin) yang belum tersentuh oleh bantuan hukum. 
Tahun 2012 sebanyak 22 (dua puluh dua) ranperda, selain itu Ranperda tentang Bantuan Hukum belum ditempatkan dalam urutan Prioritas. ${ }^{20}$ Apalagi pada Tahun 2013 merupakan tahun politik, dimana kader-kader partai politik yang ada di DPRD Provinsi Sumatera Utara disibukkan dengan agenda tahapan Pemilu Legislatif, sehingga apabila tidak didorong sulit diharapkan akan lahirnya Perda tentang Bantuan Hukum di Provinsi Sumatera Utara. Padahal pembentukan Perda Bantuan Hukum sangat penting sebagai landasan hukum bagi daerah untuk memenuhi hak-hak masyarakat miskin dalam mengakses keadilan dan perlakuan yang sama di hadapan hukum.

\section{E. Penutup}

Penyelenggaraan pemberian bantuan hukum kepada masyarakat merupakan upaya pemerintah untuk memenuhi dan sekaligus sebagai implementasi negara hukum yang mengakui dan melindungi serta menjamin hak asasi warga negara akan kebutuhan akses terhadap keadilan (access to justice) dan kesamaan di hadapan hukum (equality before the law). Undang-Undang tentang Bantuan Hukum ini menjadi dasar bagi negara untuk menjamin warga negara khususnya bagi orang atau kelompok orang miskin untuk mendapatkan akses keadilan dan kesamaan di hadapan hukum.

UU Bantuan Hukum juga memberi ruang bagi daerah untuk mengalokasikan dana penyelenggaraan bantuan hukum dalam APBD. Apabila daerah berkehendak mengalokasikan dana bantuan hukum dalam APBD, maka pemerintah daerah dan DPRD harus mengaturnya dalam Peraturan Daerah (Perda). Walaupun Rancangan Perda Bantuan Hukum Provinsi Sumatera Utara saat ini telah tercantum dalam Prolegda 2013, namun Rancangan Perda tersebut sampai tulisan ini dibuat belum juga tersusun. Mengingat pentingnya perda tentang bantuan hukum sebagai landasan hukum bagi daerah untuk memenuhi hak-hak masyarakat miskin dalam mengakses keadilan dan perlakuan yang sama di hadapan hukum, diibutuhkan komitmen kuat dari DPRD maupun Pemerintah Daerah Provinsi Sumatera Utara beserta stakeholderuntuksegeramengimplementasikan pembentukan perda Bantuan hukum serta mengalokasikan dana bantuan hukum dalam APBD sebagaimana amanat pasal $19 \mathrm{UU}$ Bantuan Hukum. Tanpa komitmen yang kuat sulit mengharapkan kelahiran Perda Bantuan Hukum.

Dengan lahirnya Perda Bantuan diharapkan tidakakan ada lagimarginalisasidanketimpangan keadilan yang terjadi kepada masyarakat miskin khususnya masayarakat di Provinsi Sumatera Utara dalam melindungi hak-haknya.

\section{DAFTAR PUSTAKA}

\section{Buku:}

Cappelletti, Mauro, Toward Equal justice : A Comparative Study of Legal Aid in Modern Societies, New York: Dobbs Ferry, 1975 )

Metzger, Barry, Legal Services to the Poor and National Development Objectives dalam buku Legal Aid and World Poverty, ( Preger Publishers, 1974)

Winarta, Frans H., Bantuan Hukum di Indonesia, Elex Media-Jakarta, 2009

Winarta, Frans H., PRO BONO PUBLICO : Hak Konstitusional Fakir Miskin Untuk Memperoleh

20 Hasil Wawancara dengan Gunadi, SH, M.Hum. (Staf Ahli Badan Legislasi DPRD Provinsi Sumatera Utara) pada tanggal 23 April 2013. 
Bantuan Hukum, Gramedia Pustaka Utama, Jakarta, 2009.

Zaidun, Muhammad, dkk, Mengajarkan Hukum Yang Berkeadilan; Cetak Biru Pembaharuan Pendidikan Hukum Berbasis Keadilan Sosial, Jakarta: ILRC, 2009.

\section{Makalah/Artikel/Prosiding/Hasil Penelitian}

Kementerian Negara Perencanaan Pembangunan Nasional/Badan Perencanaan Pembangunan Nasional, Pokja Akses terhadap Keadilan KementerianNegaraPerencanaanPembangunan Nasional/ Badan Perencanaan Pembangunan Nasional (BAPPENAS), Strategi Nasional dan Akses terhadap Keadilan, (Jakarta: BAPPENAS, 2009).

Ramly Hutabarat, Persamaan di Hadapan Hukum sebagai Antithese terhadap Diskriminasi Hukum, (Makalah disampaikan dalam Seminar Sehari yang diadakan oleh staf ahli Kementerian Hukum dan HAM RI pada tanggal 1 Desember 2011 di Aula Pengayoman Kantor Wilayah Kementerian Hukum dan HAM Sumatera Utara).

Ramly Hutabarat, Persamaan Dihadapan Hukum Sebagai Antithese Terhadap Diskriminasi Hukum, (Makalah-2011).

Rusma Dwiyana, Equality Before The Law VS Impunity: Suatu Dilema (Makalah Tanpa Tahun).

\section{Internet:}

Jawa Timur Terbanyak Dihuni Penduduk Miskin, http://www.rmol.co/news.php?id=90145 (diakses tanggal 22 April 2012).

Jumlah Penduduk Miskin Sumut Diklaim Tinggal 10\%, http://economy.okezone. com/ read/2013/01/03/20/740611/jumlahpenduduk-miskin-sumut-diklaim-tinggal-10 (diakses pada tanggal 22 April 2013) 